Article

\title{
Reversed Crystal Growth of Calcite in Naturally Occurring Travertine Crust
}

\author{
Heather F. Greer ${ }^{1,+}$, Wuzong Zhou ${ }^{1, *}$ and Li Guo ${ }^{2}$ \\ 1 EaStCHEM, School of Chemistry, University of St Andrews, St Andrews, Fife KY16 9ST, UK; \\ hfg@st-andrews.ac.uk \\ 2 CASP, Department of Earth Sciences, University of Cambridge, West Building, 181a Huntingdon Road, \\ Cambridge CB3 0DF, UK; li.guo@casp.cam.ac.uk \\ * Correspondence: wzhou@st-andrews.ac.uk; Tel.: +44-1334-467276; Fax: +44-1334-463808 \\ + Current Address: Department of Chemistry, University of Cambridge, Lensfield Road, \\ Cambridge CB2 1EW, UK.
}

Academic Editors: Helmut Cölfen and Monica Distaso

Received: 30 August 2016; Accepted: 22 January 2017; Published: 28 January 2017

\begin{abstract}
A microstructural investigation by electron microscopy on a travertine specimen collected from Munigou National Park, Sichuan Province, China revealed evidence of a non-classical reversed crystal growth route previously only discovered in synthetic materials. Examination of the travertine specimen suggests that the presence of organic matter initiates the oriented aggregation of calcite nanocrystallites. Surface re-crystallisation of the aggregates leads to a single crystalline rhombohedral shell with a polycrystalline core. This core-shell structure carries a strong resemblance to synthetic calcite prepared in the presence of chitosan, where the growth of calcite was found to follow the so-called reversed crystal growth process. It is proposed that the similar roles of biomolecules in naturally occurring travertine and chitosan in the synthetic system are based on their isoelectric points and the polymerizable property of long chain chemical structures. This study is important so that the structural similarities between naturally occurring biominerals and biomimetic materials can be further understood.
\end{abstract}

Keywords: travertine; electron microscopy; crystal growth; calcite; minerals; biological macromolecules

\section{Introduction}

Calcium carbonate is an exceptional compound that exists everywhere in nature and makes up more than $4 \%$ of the Earth's crust which makes the polymorphs calcite, aragonite and vaterite some of the most important rock-forming minerals [1,2]. The present study focusses on travertine, which is a form of limestone normally deposited in springs, during the transfer of carbon dioxide from ground water in a spring, which is highly charged with calcium and bicarbonate. These highly porous lateral deposits form during rapid degassing when the water meets the atmosphere and subsequently cools [3]. There is a long history of disagreement regarding the definition of the terms "travertine" and "tufa" [4,5], but typically "travertine" refers to warm or hot calcareous hydrothermal deposits whereas the latter refers to ambient or cool temperature deposits [6]. This distinction is difficult to maintain, because as thermal spring waters flow downslope into pools or flat areas, they are often mixed with rainwater and the temperature changes. In this study, the temperature of spring water, $20^{\circ} \mathrm{C}$, at Munigou is higher than the annual mean air temperature, $7^{\circ} \mathrm{C}$. Travertine is a more appropriate term for these deposits rather than ambient calcareous tufa. At present, literature detailing the structural characterisation of calcite minerals via electron microscopy at the nano and atomic level formed in a geothermal spring is sparse. Previously, Kim et al. used a SEM/TEM-EELS study to characterise $\mathrm{CaCO}_{3}$ deposited in filamentous cyanobacterial mats at different locations in a hot 
spring [7]. Coman et al. described the structure and diversity of microbial mat communities associated with $\mathrm{CaCO}_{3}$ deposits in different temperature environments around a geothermal spring from an abandoned oil well drill site [8].

Similar to many other naturally occurring biominerals, travertine deposits commonly contain embedded organic matter of several weight percent with the most prominent region of organic matter being the microbial biofilm [3]. Biofilms are generally bacterial populations and communities in an extracellular polymeric substance (EPS) matrix, attached to substrates in an aquatic environment [9]. Diatoms, bacteria and cyanobacteria are able to secrete large quantities of EPS, which are essentially microfibrillar and polysaccharide in composition [10]. Negatively charged EPS has several roles, to provide physical and chemical protection to cells, facilitate communication between cells through cell-cell recognition and to preferentially induce the nucleation and precipitation of calcite by binding to the surface of $\mathrm{Ca}^{2+}$ [11]. Although the exact composition of EPS will vary depending on the type of microorganisms and the environmental conditions under which the biofilms exist, EPS is usually high molecular weight biopolymers primarily consisting of polysaccharides, as well as small quantities of proteins, nucleic acids and lipids. Due to these components, the isoelectric point of EPS is always in the acidic range although the exact value is unique to the conditions of the individual system [12]. These microorganisms are embedded in their self-produced matrix of EPS. The bioactivities of the biofilm were found to be crucial, as its absence has been known to prevent the precipitation of low $\mathrm{Mg}$-calcite [13]. To help explain the $\mathrm{CaCO}_{3}$ precipitation processes associated with freshwater microbial biofilms, Pedley set up at non-invasive flowing water experimental mesocosm, run under near-natural conditions for a period of 2.5 years [14]. Lamination of carbonate sediments is a competitive interaction between microbial growth and carbonate precipitation [15]. In highly supersaturated water, the precipitation rate of minerals is rapid but at a variable rate according to hydrological conditions, and flow conditions are known to result in a multitude of carbonate textures and microbial components within a single travertine [16,17].

EPS may work in a similar way to the organic agents often added to biomimetic systems. For example, crystals of $\mathrm{CaCO}_{3}$ [18-24], $\mathrm{ZnO}[25-28]$, and fluorapatite $[29,30]$ have been grown in gel matrices or in the presence of polymers such as gelatin, chitosan, gum arabic and agarose. During the preparation process, these structure directing agents may play the role of a template and a surfactant. A careful selection of the structure directing agent is necessary as their ability to selectively adsorb onto a preferred surface allows many factors such as the polymorphic phase, the nucleation, alignment of crystallites, and also the morphology to be stringently controlled [31-33]. Similar hierarchical microstructures have been described for biogenic calcite, where organic macromolecules and inorganic mineral form a hybrid structure over many length scales $[34,35]$. Bacterial mediated carbonate biomineralisation systems are known to be even more complex and display a wide variety of crystal morphologies, many of the reasons for their formation are not well known [36,37].

In more recent years, investigations of the early stage morphologies of some organic and inorganic systems have found that their crystal growth does not always follow the more traditional classical crystal growth route established approximately 150 years ago. Instead, non-classical pathways such as reversed crystal growth route [38], oriented attachment of primary particles forming an iso-oriented crystal upon fusing or the self-assembly of primary particles covered with organics to form a mesocrystal are deemed more suitable [39]. The classical growth route assumes free crystals with a highly symmetric polyhedral morphology develop via nucleation and a layer-by-layer deposition of atoms, molecules or ions to a single nucleus via an epitaxial type process [40]. This well-established growth route can be defined using the Bravais-Friedel-Donnay-Harker (BFDH) law [41-43], Hartman-Perdok theory [44] and Ostwald ripening [45,46]. The BFDH law assumes a linear growth rate, $\mathrm{r}_{\mathrm{hkl}}$, where the crystal face is inversely proportional to the interplanar distance, $\mathrm{d}_{\mathrm{hkl}}$, and therefore the slowest growing faces are those with the greatest interatomic spacing. Using periodic bond chain theory, Hartman and Perdok refined the BFDH model by attempting to quantify the crystal morphology in terms of the interaction energy between crystallising units. In instances 
where surfactants or polymers were introduced the crystal growth has often been found to follow an increasingly common non-classical reversed crystal growth route. This growth route, founded in 2007, in which re-crystallisation starts at the surface of an aggregate of polycrystalline zeolite analcime particles, forming a "core-shell" structure where a highly symmetric and high density shell surrounds a disordered core, followed by an extension of re-crystallisation from the surface to the core. This non-classical reversed crystal growth route was induced by organic ethylamine molecules, added as a modification to a well-established synthetic method [47] for zeolite analcime. These molecules adsorbed onto the surface of the early stage nanoparticles [48]. This reversed crystal growth route can be generalised by the four principal stages, nanocrystallites, aggregation, surface re-crystallisation and finally single crystal.

In general, the formation mechanism and the role of the biomolecules in the construction of travertine deposits and most other naturally occurring biominerals have been extensively investigated yet, due to many variables involved questions regarding the structure and formation mechanism of the resulting mineral remain. One reason is that the most investigations tend to focus on echinoderms and nacre rather than less common biomineralisation systems. These investigations have a tendency to focus solely on characterisation of the structure but few follow up with a formation mechanism [49-51]. One effective way to overcome this is to replicate the structure of natural occurring biominerals such as that done by Finnemore et al. in nacre [52]. Not only did their ordered multilayer structure of $\mathrm{CaCO}_{3}$ platelets separated by porous organic layers strongly resemble the biogenic material, its mechanical and optical properties also bear a striking similarity. Another reason for the limited knowledge of the formation mechanism of travertine deposits is that most previous studies have used optical microscopy and scanning electron microscopy (SEM) to show the morphology and the surface of the crystals $[53,54]$. In the present work, high resolution SEM has been combined with high resolution transmission electron microscopy (HRTEM) in order to reveal the microstructure of natural travertine at atomic resolution. Finally, we report a comparative study of the structure and formation mechanisms of natural travertine with those obtained from previously reported biomimetic calcite prepared in the presence of chitosan [18].

\section{Results}

\subsection{Travertine Calcite Deposits}

The travertine calcite deposits were collected at Erdaohai in Munigou Valley National Park, which is located in the northern part of the Sichuan Province, China (Figure 1). The photomicrograph image of the travertine sample stained with a mixture of potassium ferricyanide and alizarin red $S$ in Figure 2 shows a uniform sample consisting of aggregates of calcite microparticles. According to the XRD pattern in Figure 3 the travertine specimen is monophasic and can be indexed to rhombohedral calcite with unit cell parameters of $a=4.99, c=17.06 \AA$, space group R $\overline{3} \mathrm{c}$ (JCPDS card No. 47-1743). Although this travertine deposit, formed from the naturally occurring biomineral calcite was expected to contain impurities, EDX (inset of Figure 3) of the calcite particles was only able to detect the principle elements of calcium, carbon and oxygen indicating a $\mathrm{CaCO}_{3}$ phase. However, co-existed organic molecules containing only light elements cannot be ruled out. The $\mathrm{Cu}$ in this spectrum is from the copper grid, on which the sample was deposited for TEM investigations.

By studying several different regions along a profile across several layers of the travertine sample, calcite particles displaying different morphologies and surface details were detected. It is expected that these particles have grown over various periods of time. The earliest detected morphology is thought to be nanoparticles, ca. 130-230 nm in dimension surrounded by a network of EPS fibres (Figure 4a). A second observed morphology in this studied travertine specimen is irregular shaped aggregates with a dimension of 3 to $8 \mu \mathrm{m}$ as shown in Figure $4 \mathrm{~b}$. The travertine calcite particles in Figure $4 \mathrm{~b}$ are composed of 200 to $350 \mathrm{~nm}$ sized polyhedral particles as the building unit. The dimensions of these building units are consistent with the size of the particles in Figure 4a. These aggregates contain a 
large number of needles (marked by arrows in Figure 4b), which appear to frequently lie parallel to the traces of the (104) planes of the calcite subunits in the aggregates and intersect at an angle appropriate for a rhombohedral morphology. The building units in aggregates, similar to that in Figure 4c, were found to terminate with the same plane as indicated by dashed lines (Figure S1a, where S indicates Supplementary Materials). The arrangement of polyhedral building units in the calcite particles shown in Figure $4 \mathrm{c}$ is significantly denser compared to the aggregate in Figure $4 \mathrm{~b}$.

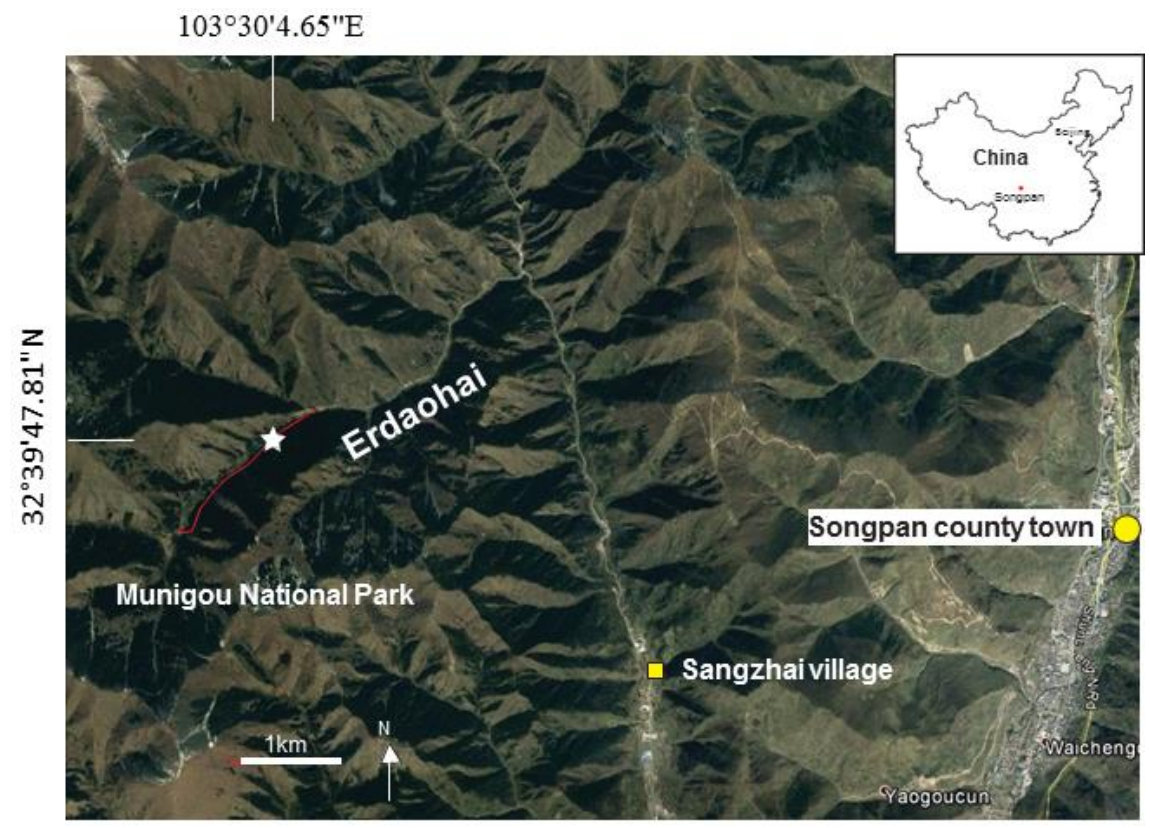

Figure 1. Location of Erdaohai valley (red line) with travertine deposits in the Munigou National Park, north Sichuan, China. The star indicates the location of studied sample (32 $\left.39^{\prime} 47.81^{\prime \prime} \mathrm{N} 103^{\circ} 30^{\prime} 4.65^{\prime \prime} \mathrm{E}\right)$. The satellite image is from Google Earth.

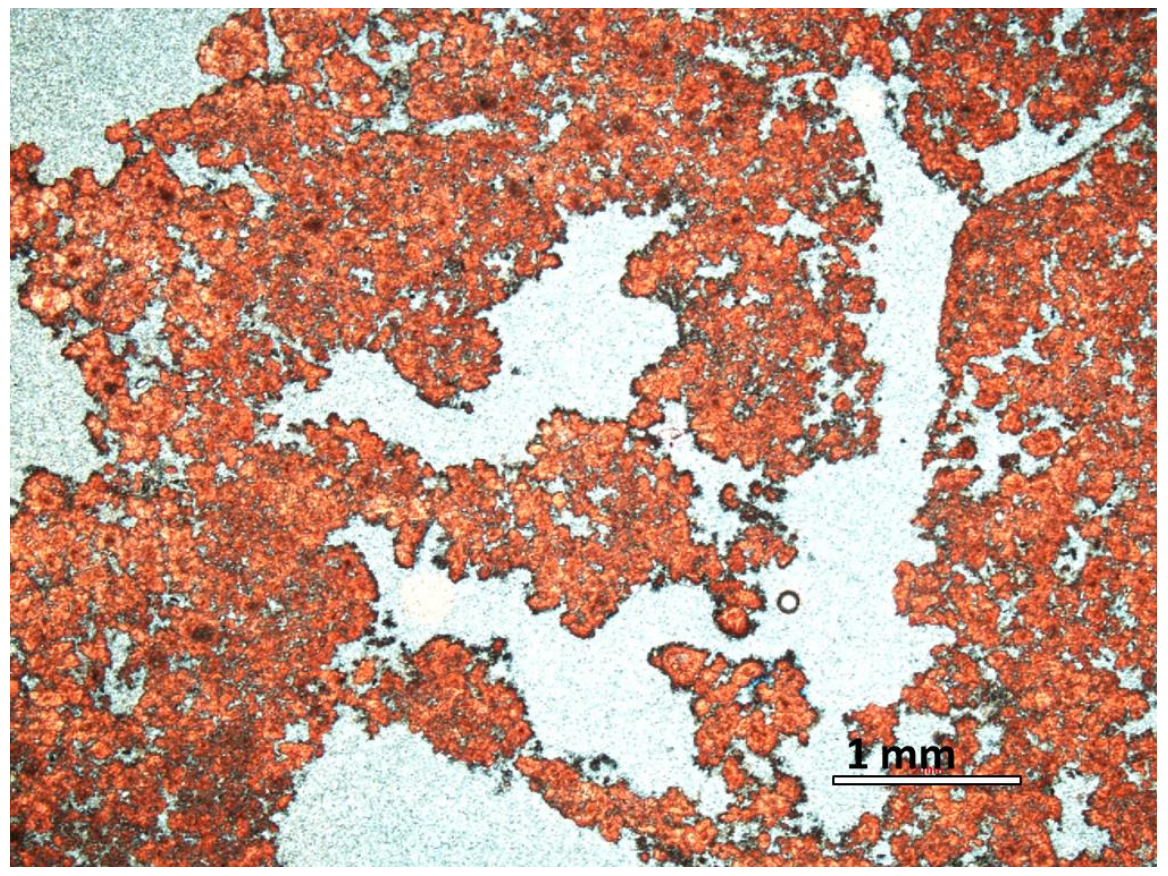

Figure 2. Photomicrograph of calcite, stained with a mixture of potassium ferricyanide and alizarin red $\mathrm{S}$, under plane polarised light. 
The profiles of some particles in Figure 4c are partially obscured by a coating or film (marked by arrows). These molecules with an unknown composition can be regarded as EPS molecules. EPS molecules were found to be more noticeable at the microbial biofilm region (Figure S2a) although long filaments of EPS, ca. 500-700 nm thick and tens of microns long, could be easily distinguished by SEM (Figure S2b). TGA (Figure S3) carried out on the travertine specimen showed a weight loss between 230 and $380{ }^{\circ} \mathrm{C}$, indicating the travertine crystals contained approximately $2.1 \mathrm{wt} \%$ EPS molecules. The SEM image in Figure $4 \mathrm{~d}$ shows a travertine calcite particle exhibiting a much more regular rhombohedral shape despite displaying a rough surface. Travertine calcite particles at a later growth stage are thought to be those with a smoother surface (Figure 4e) although the surface topography can vary slightly from particle to particle (Figure $4 \mathrm{f}, \mathrm{g}$ ).

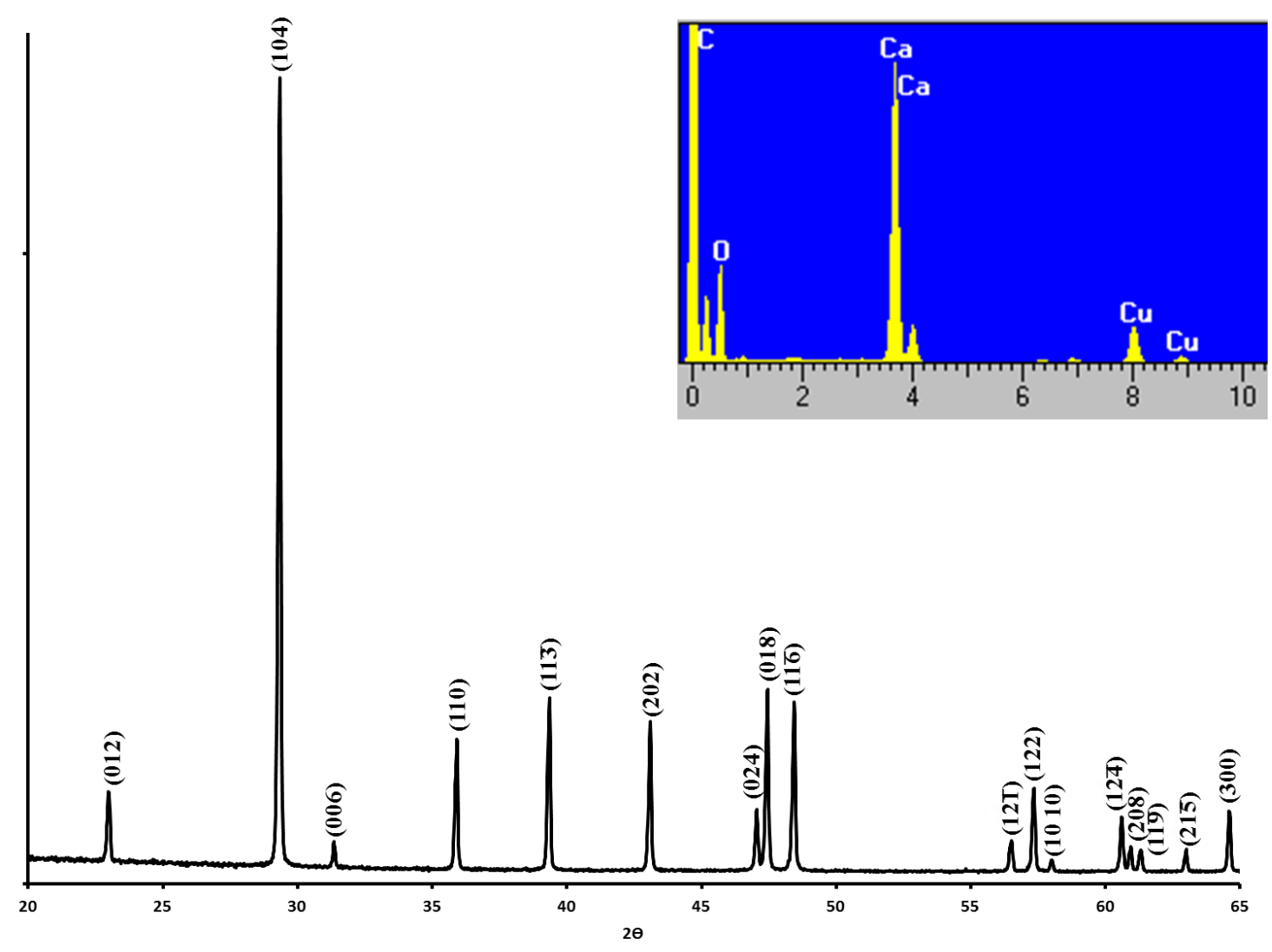

Figure 3. XRD pattern of travertine specimen indexed to a rhombohedral calcite phase. The inset shows a typical EDX spectrum attained from several calcite fragments on the TEM.

Very few calcite particles in the present travertine system exhibit a perfect rhombohedral shape, which is a common characteristic of single crystals of calcite although most display rhombohedral habits. When such a perfect rhombohedral particle present in the travertine specimen was fractured, a core-shell structure was revealed (Figure $4 \mathrm{~h}$, Figure S1b), i.e., a polycrystalline core encased in a single-crystal shell with a thickness on the order of tens of nanometres. It is highly plausible that the partially disordered core, particularly in the lower region of the particle, shown in Figure $4 \mathrm{~h}$ was generated by strain during intentional fracturing since many of crystallite building units in the suspected earlier stage calcite particles have a uniform orientation (Figure $4 \mathrm{~b}, \mathrm{c}$ ). The core region contains some small areas covered in a film of EPS molecules (marked by arrows in Figure 4h), as evidence of embedded organic molecules. 

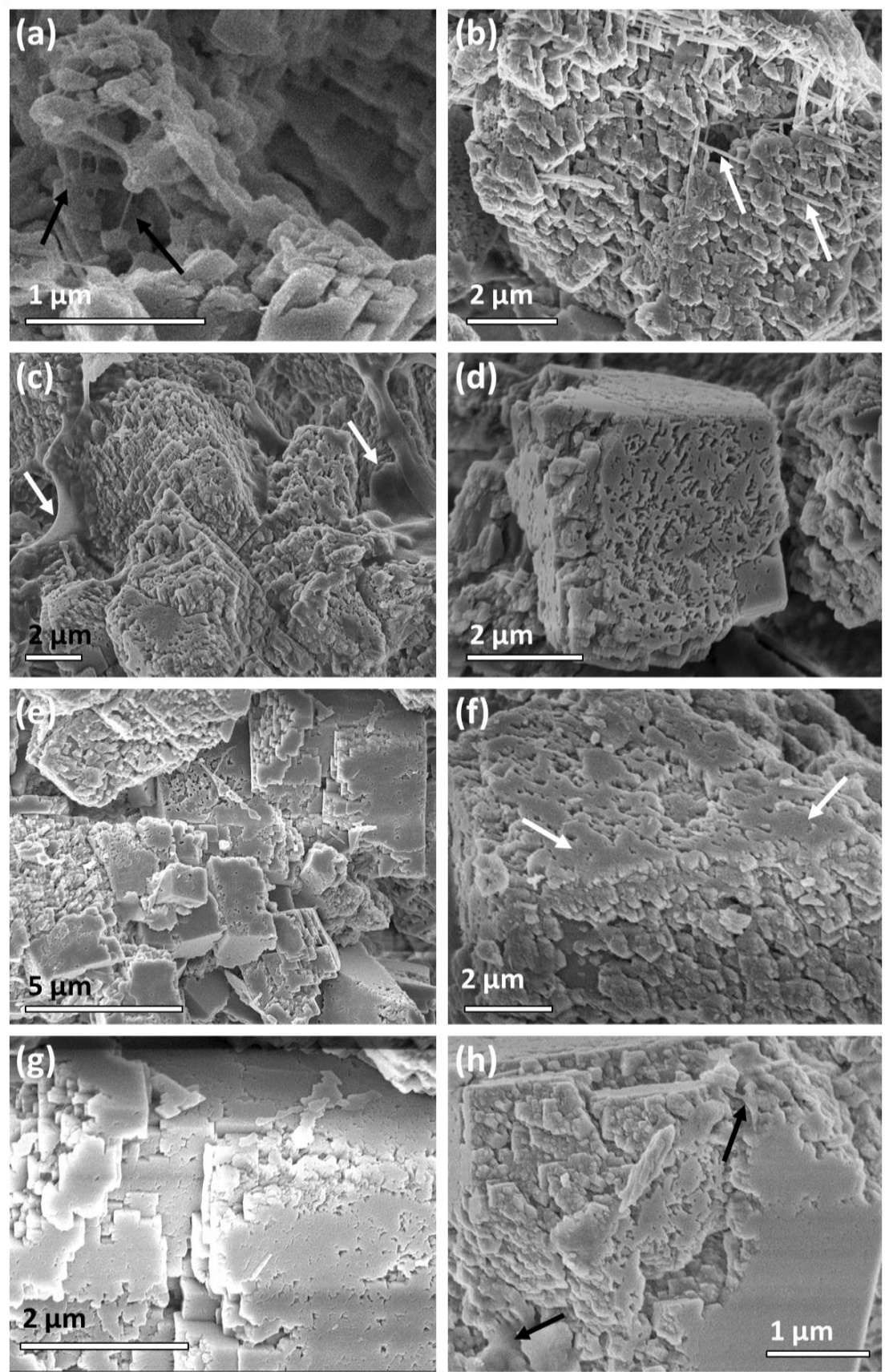

Figure 4. SEM images of calcite particles found in the travertine specimen at various stages of growth. (a) Nanoparticles of calcite trapped inside a matrix of EPS fibres (marked by arrows); (b) An irregularly shaped polycrystalline aggregate. The arrows mark embedded calcite needles; (c) Calcite aggregate composed of a dense arrangement of nanosized building units. The arrows mark EPS molecules; (d) Calcite particle displaying a more regular rhombohedral morphology; (e) Low magnification image showing calcite particles with a relatively smooth surface; (f) Calcite particle exhibiting many single crystalline surface domains as evidence of surface re-crystallisation. The arrows mark large single crystalline regions on the surface of a rhombohedral particle; (g) Calcite particle displaying a significantly smoother surface; A lower magnification SEM image of this particle is shown in the upper right side of (e); (h) A fractured calcite particle exposing a core-shell structure: a thin single crystalline shell surrounding a polycrystalline core; The arrows in (h) mark embedded EPS molecules. 
HRTEM was carried out to reveal differences in nanostructure of the calcite travertine particles with different morphologies and to establish if the polyhedral building units in the calcite particles were oriented. The TEM image in Figure $5 \mathrm{a}$ as recorded from the edge of a rhombohedral particle shows polyhedral nanoparticles with a dimension of $100 \mathrm{~nm}$. Differences in contrast in the polyhedral particles suggest they are constructed from 10 to $20 \mathrm{~nm}$ sized domains. The single crystal-like fringes and the outline of many domains in Figure $5 b$ indicate that all the domains have a uniform orientation. The uniform orientation was further confirmed by recording a selected area electron diffraction (SAED) pattern from a large area of a calcite particle containing many nanocrystallites (Figure S4a). The terminal planes of the surface terraces are parallel (marked by arrows in Figure S4b) which also suggests a uniform orientation. The TEM image in Figure $5 c$ as recorded from another calcite particle shows significantly larger sized $(\sim 250 \mathrm{~nm})$ crystallites. Nanodomains with a size of 10-20 nm cannot be distinguished which indicates this calcite particle has a higher crystallinity. D-spacings measured from the marked lattice fringes Figure $5 b, d$ can be indexed to the (006) and (104) crystal planes of calcite with an interplane angle of $44.6^{\circ}$. The pale contrasted amorphous regions observed in HRTEM images (Figure $5 b, d$ ) are either pores or EPS rich areas. In addition, TEM provided further evidence of a core-shell structure (Figure S4c,d). A dark contrasted layer with a uniform thickness of $30 \mathrm{~nm}$ was observed at the surface of the rhombohedral travertine particle.
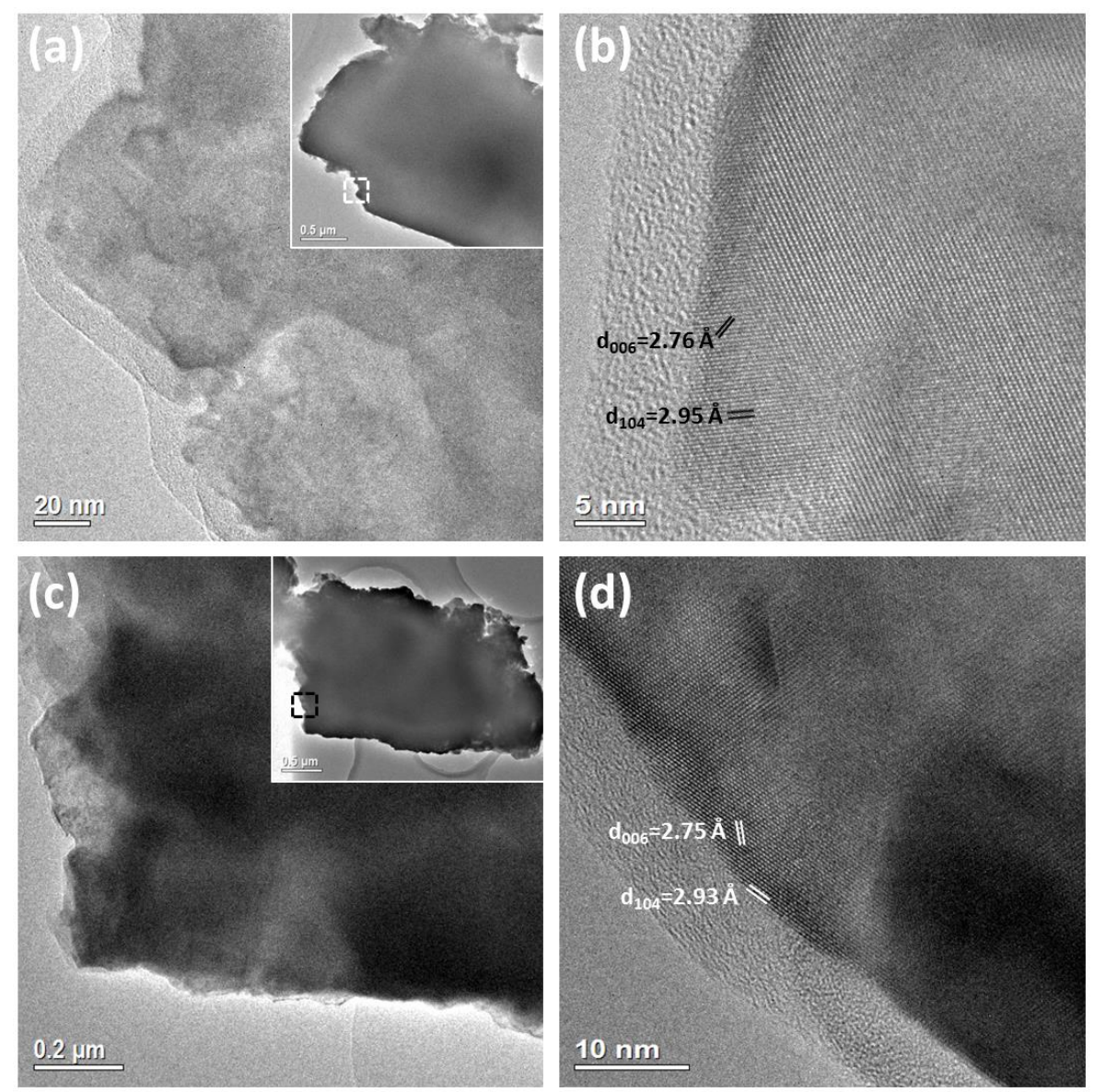

Figure 5. (a,c) TEM images recorded from calcite particles in the travertine specimen that are thought to have different growth times; The particle size is shown to be (a) $100 \mathrm{~nm}$; and (c) 250-300 nm, respectively. The corresponding low magnification TEM images are shown in the insets; $(\mathbf{b}, \mathbf{d})$. The HRTEM images were recorded from the area marked by a square in the inset of $(\mathbf{a}, \mathbf{c})$; The HRTEM image in $(\mathbf{b})$ shows many 10-20 nm sized domains; The marked crystal fringes in (b,d) can be indexed to the (104) and (006) crystal planes of calcite. 


\subsection{Synthetic Calcite Grown in the Presence of Chitosan}

As a comparative study for our travertine calcite, synthetic calcite was grown in chitosan gel [18]. Details on the synthetic method are outlined in the Supplementary Materials. The typical morphologies of calcite at different growth stages as a result of thermal treatment times ranging from $2 \mathrm{~h}$ to 9 days are displayed in Figure 6. Despite the regular rhombohedral appearance at $2 \mathrm{~h}$, the calcite crystals were found to be aggregates of small particles rather than single crystals (Figure 6a). In fact, nanocrystallites on the surface were clearly visible at higher magnifications (Figure $6 \mathrm{~b}$ ). When the reaction time was increased to $23 \mathrm{~h}$ the rhombohedral particles had much smoother (104) surfaces (Figure 6c) although their faces had a rougher topography in the centre compared to the edges (Figure 6d).
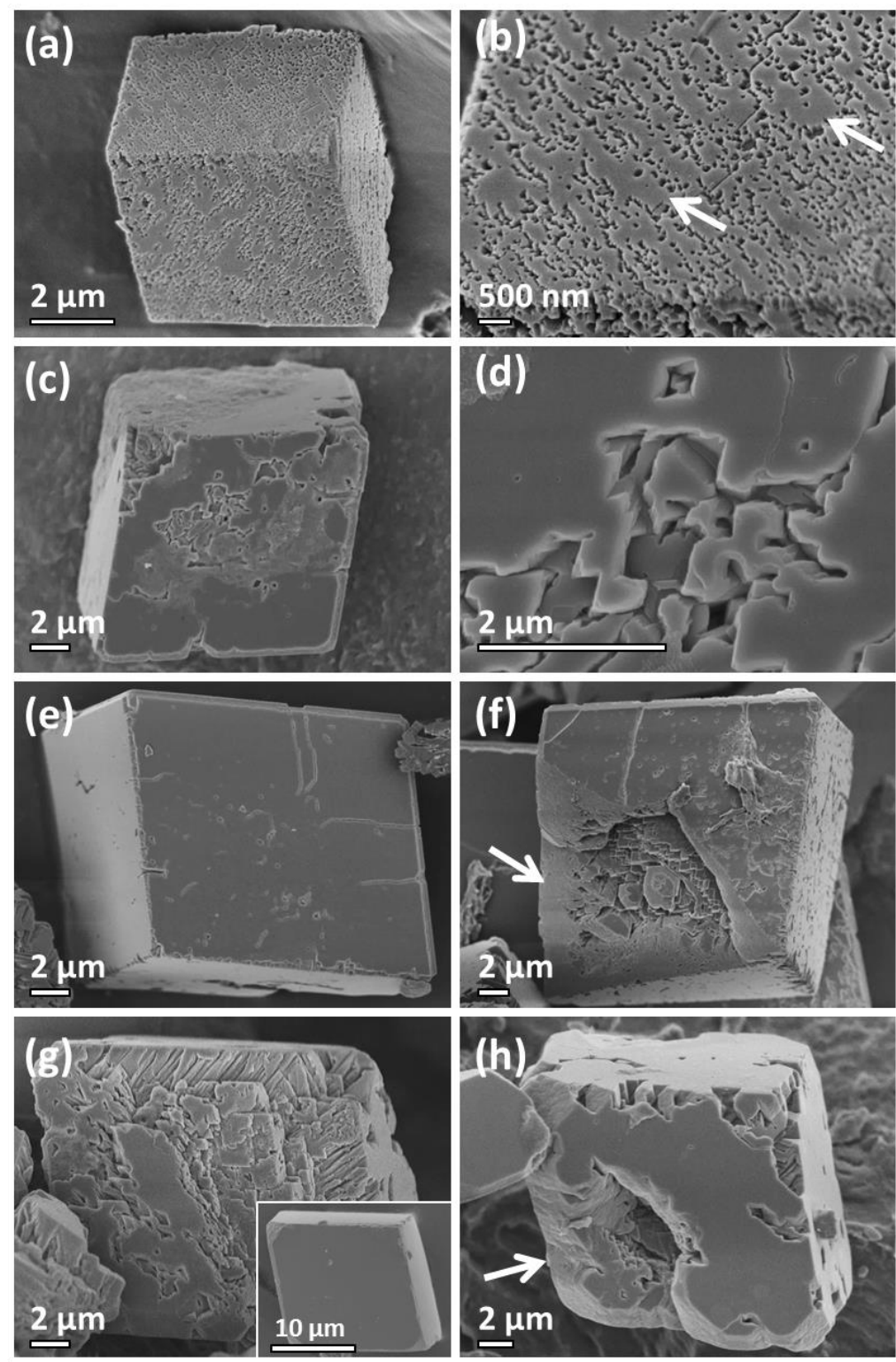

Figure 6. SEM images of synthetic calcite particles prepared in the presence of chitosan with a hydrothermal treatment time of $(\mathbf{a}, \mathbf{b}) 2$ h; (c,d) 23 h; (e,f) 3 days; and $(\mathbf{g}, \mathbf{h}) 9$ days. The inset of $(\mathbf{g})$ shows an unbroken particle; Low magnification images of the rhombohedral particles are shown in $(\mathbf{a}, \mathbf{c}, \mathbf{e}, \mathbf{g})$; The corresponding high magnification images of their surface are shown in (b,d); and images of fractured particles in (f,h). 
At 3 days the surfaces of the rhombohedral particles were completely smooth (Figure 6e). Although the rhombohedral outer appearance of the calcite particles is characteristic of a single crystal, when fractured a core-shell structure was revealed (Figure 6f). The high density shell with a thickness of $\sim 2.5 \mu \mathrm{m}$ encloses a self-oriented polycrystalline core. Finally, when the growth time was increased to 9 days, the particle size and morphology remained constant as demonstrated by the SEM micrograph shown in the inset of Figure $6 \mathrm{~g}$ but the thickness of the shell increased to $\sim 4.5 \mu \mathrm{m}$ as shown by Figure $6 \mathrm{~h}$. The SEM image in Figure $6 \mathrm{~g}$ shows a 9 day fractured calcite particle containing a high density surface layer in comparison to the polycrystalline core. The cross-section of the surface layer with a thickness of $\sim 4 \mu \mathrm{m}$ appears as rods. This rod type structure may be the result of crystal cleavage of the surface.

The TEM image in Figure S5a, recorded from a fragment of a $2 \mathrm{~h}$ calcite particle revealed a nanodomain structure with sizes in the range of $15-50 \mathrm{~nm}$. The pale contrasted amorphous regions (marked by arrows) located in-between domains are likely pores filled with chitosan molecules. It has not been possible to determine a $\mathrm{wt} \%$ value for the amount of embedded chitosan within the calcite particles due to poor solubility of chitosan in the present synthetic conditions. Due to the remainder of a large quantity of undissolved chitosan, TGA would have provided a hugely inaccurate result. A method commonly used to detect organic materials inside biominerals [55] and biomimetic materials [56] is etching. Figure S5b shows a HRTEM image recorded from a region in Figure S5a. The $d$-spacings measured from the marked diffraction spots in the fast Fourier transform (FFT) pattern shown in the inset of Figure S5b are $3.85 \AA$ and $2.79 \AA$ A respectively, corresponding to the (012) and (006) calcite crystal planes with an interplane angle of $63^{\circ}$. The lattice fringes and corresponding FFT pattern in Figure S5b combined with the single crystal-like SAED pattern (Figure S5c) recorded from a large area of a $2 \mathrm{~h}$ calcite particle confirms the uniform orientation of the nanodomains. It should be noted that when calcite is prepared in total absence of organic agents the core-shell structure is absent but the rhombohedral morphology is maintained (Figure S6). The calcite particles were real single crystals with no visible domains as confirmed by HRTEM.

\section{Discussion}

The present investigation has discovered that the crystal growth of the travertine calcite deposits comprising a rhombohedral core-shell structure strongly resemble synthetic calcite crystals prepared when either chitosan or gum arabic gel was added as an organic structure directing agent [18]. In particular, the early stage step-by-step growth of calcite prepared in the presence of chitosan was found to be an effective simulation for the growth of the calcite particles in the travertine specimen. As a result, the roles of chitosan and EPS molecules are expected to be very similar. Such roles of the biomolecules are thought to include the enhancement of aggregation and the attraction of calcium cations in the early growth stages. High amounts of hydrogel network incorporated into the crystals under supersaturated conditions are known to impose a significant effect on calcite morphology, aggregate formation and co-orientation although this matrix incorporation greatly depends on gel strength and concentration, i.e., solid content termed by $\mathrm{wt}^{\mathrm{t}} \%$, as well as mineral growth rate [57]. Gel networks can affect the chemical functionality within the gel by modifying the diffusion rates of solutes and therefore local concentrations. This will affect local supersaturation and ultimately suppress or enhance nucleation as well as modify the resulting morphology. To further complicate matters, the appearance of the surfaces of aggregates has been found to vary as a function of position in the gel: particles formed closest to the $\mathrm{Ca}^{2+}$ source showed rough surface terraces, characteristic of high supersaturation conditions, while those closest to the $\mathrm{CO}_{3}{ }^{2-}$ source had smooth, faceted surface terraces, typical of lower supersaturation conditions [58]. The observation of multiple morphologies within the same gel matrix emphasizes the importance of fully understanding the role of growth conditions, and supersaturation, on the final structure although it is often difficult to determine the individual contributions of these factors. 
The SEM images of our early stage travertine calcite particles show that they are trapped within a matrix of EPS molecules. This is consistent with geological literature, where it was previously stated that precipitates always developed in two locations: within the biofilm, where loosely adherent cyanobacterial filaments lying close to each other formed hammocks or second, within discrete isolated low viscosity EPS clouds on the vacuolar floor areas [14]. Synthetic calcite grown in Mg-bearing gelatin hydrogel has previously produced highly porous crystals with similar morphologies [22]. The observed microstructures of travertine calcite in the present work are due to growth within a biofilm. Knowledge of the structure of biofilm-containing calcite mineral deposits in geothermal habitats has been extensively investigated although further studies are necessary to fully understand the geomicrobiological processes and formation mechanism of laminated travertine $[7,8]$.

EPS molecules are amphiphilic with positively and negatively charged groups, as well as hydrophilic and hydrophobic groups [59]. Functional groups in EPS have been reported to include carboxyl, phosphoric, amine, phenolic and hydroxyl [60]. Based on the large number of available carboxyl and hydroxyl groups, EPS is regarded to have a very high binding capacity [61]. The adsorption behaviour of EPS on different surfaces is largely unknown but previous studies have concluded that solution chemistry, such as the ionic strength and $\mathrm{pH}$ can dramatically impact the EPS deposition or adsorption [61]. To address this problem Zhang et al. [62] prepared four self-assembled monolayers (SAM) carrying SAM- $\mathrm{CH}_{3}, \mathrm{SAM}-\mathrm{NH}_{2}, \mathrm{SAM}-\mathrm{OH}$ and $\mathrm{SAM}-\mathrm{COOH}$ terminal groups and investigated the attachment and adsorption of EPS on these surfaces under different $\mathrm{pH}$ values and valences of additional cations using surface plasmon resonance. $\mathrm{Ca}^{2+}$ was discovered to encourage EPS adsorption by forming EPS complexes. The $\mathrm{Ca}^{2+}$ complexes were attracted by $\mathrm{COOH}-\mathrm{SAM}$ but repelled by $\mathrm{NH}_{2}-\mathrm{SAM}[62]$.

Without in situ electron microscopy combined with all the complications that come with investigating the crystal growth of natural biominerals, we should consider a small possibility that, like many other biominerals, travertine calcite particles may have originated via an amorphous calcium carbonate (ACC) precursor. Seto et al. [34] discovered that during the crystallisation of mesocrystalline spicules in sea urchins they appeared to be able to retain 'memory' of the original ACC particles. This gave rise to mesocrystals comprising a 3D array of iso-oriented particles containing embedded macromolecules, which TEM data found were distinguishable from single crystals generated via the classical growth mechanism.

Irregular shaped aggregates such as those shown in Figure $4 \mathrm{~b}$ are consistent with oriented aggregation or the formation of skeletal biominerals, such as calcitic octocoral sclerites [63]. Similar surface features of identically sized and hierarchically arranged rhombohedral sub-blocks in calcite particles prepared in hydrogels of gelatin were observed by Nindiyasari et al. [24]. Skeletal crystals are hollow crystals, grown under disequilibrium conditions where their walls, either solid or constructed from subcrystals form before their cores. This growth proceeds in a reverse pattern of normal growth by subsequent precipitation in the core to develop solid skeletal crystals [64]. Despite the outer morphological similarities of our calcite crystals, skeletal growth cannot be used to explain the formation of a core-shell structure on an already solid particle nor the formation of a high density single crystalline shell [38].

Such an aggregation process was commonly observed as the first step in the so-called reversed crystal growth route [65]. Song and Cölfen have discussed mechanisms demonstrating the assembly of a number of mesocrystals in detail [66]. The term mesocrystal was originally used to describe crystals formed via the oriented assembly of polymer stabilised crystalline nanoparticles. This definition has since been relaxed such that mesocrystal is now based on structure and not formation mechanism [34]. Kim et al. [67] recently outlined some common misinterpretations in $\mathrm{CaCO}_{3}$ mesocrystals, in stating that calcite/polymer crystals frequently may not have nanoparticle substructures.

Needles, which were frequently located within these aggregates, are most probably calcite although their contribution to the formation of these aggregates is not known. Pedley [14] observed similar needles of calcite, which were said to develop by entombing the sheaths of several parallel 
oriented erect, living cyanobacterial filaments. The crystal $c$-axis was reported to be oriented parallel to the long axes of the filament.

As well as studying the time dependent crystal growth of calcite, Ritchie et al. [18] investigated the addition of agents with differing isoelectric points, 6.8-7.4 for chitosan and 1.8 for gum arabic. Although a core-shell structure followed by a true single crystal was achieved in both systems, stronger interactions were observed between the polar $-\mathrm{OH}$ and $-\mathrm{NH}_{2}$ groups of gum arabic and the $\mathrm{Ca}^{2+}$ cations compared to the calcite-chitosan system. The lower isoelectric point of gum arabic and thus stronger interactions between this agent and $\mathrm{Ca}^{2+}$ cations led to a faster aggregation of $\mathrm{CaCO}_{3}$ precursors. As an extension of the previous work, gelatin (type B) with an isoelectric point in the range 4.7-5.2, which lies between the values reported for gum arabic and chitosan, is suggested as a suitable structure directing agent for calcite. Rather than yielding rhombohedral calcite with a core-shell structure such as that achieved in the travertine sample and $23 \mathrm{~h}$ specimens prepared using chitosan and gum arabic [18], calcite prepared using gelatin had an eight armed star-like morphology with varying degrees of terraced excavations on each $\{104\}$ face (Figure S7). Calcite with a very similar 8 -armed star appearance, originating from rhombohedral shaped calcite crystals has previously been produced by the crystallisation of $\mathrm{CaCO}_{3}$ in agarose gels [68].

\section{Formation Mechanism}

Following an electron microscopic analysis of calcite particles in a travertine specimen and synthetic calcite prepared in the presence of chitosan molecules [18] with a series of different reaction times, significant evidence has been found to prove that the calcite particles in both these natural and synthetic systems do not grow via a classical route. Instead a non-classical reversed crystal growth route is proposed as illustrated by the six principle steps in Figure 7.

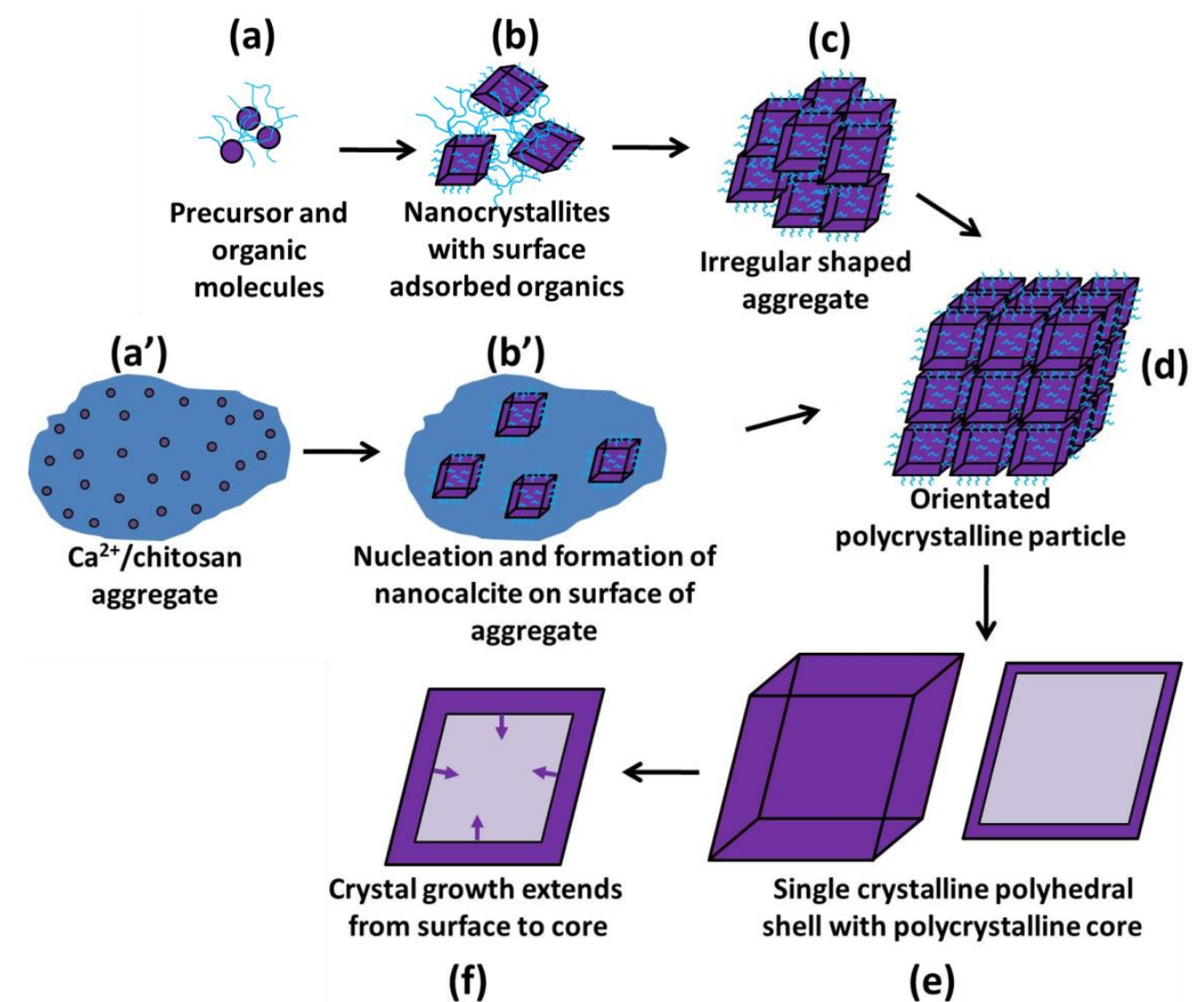

Figure 7. Schematic drawing of the proposed growth mechanism of calcite in the travertine crust specimen (a-f) and those prepared using a synthetic method with chitosan $\left(\mathbf{a}^{\prime}, \mathbf{b}^{\prime}, \mathbf{d}-\mathbf{f}\right)$. 
In the early stage growth of travertine deposits, the presence of a microbial film consisting of negatively charged EPS molecules is thought to mediate the nucleation and precipitation of $\mathrm{CaCO}_{3}$ following the transfer of $\mathrm{CO}_{2}$ from ground water highly charged with calcium and bicarbonate ions [69] (Figure 7a). It is thought that in the very early stages, EPS molecules with - $\mathrm{COOH}$ and $-\mathrm{OH}$ terminal groups of the polysaccharide adsorbed onto the (104) surface of the calcite nanocrystallites (Figure 7b). This suppressed any further growth of the individual crystallites, most likely along the [104] direction, and is thought to be the main reason for the formation of irregular shaped aggregates constructed from oriented subunits. An indication of the speed of oriented aggregation is given by the initial formation of irregularly shaped microcrystals (Figure 7c) followed by those with a highly symmetric rhombohedral morphology (Figure 7d). The outer appearance of the rhombohedral shaped calcite microstructures with a textured surface, i.e., Figures $4 \mathrm{c}-\mathrm{g}$ and $6 \mathrm{a}-\mathrm{d}$, is remarkably similar to skeletal calcite grown in polyacrylamide hydrogel whose crystal growth was proposed to proceed via precipitation, aggregation followed by oriented fusion of temporarily stabilised nanoparticles [63].

An important phenomenon, the fusing of calcite nanocrystallites, is thought to have been observed in higher magnification SEM images resulting in the formation of smooth areas on the surface of the calcite crystals. The change in the surface of the calcite microcrystals from rough to smooth with no apparent increase in particle size cannot be explained by a simple attachment of solutes onto a growing crystal. A surface re-crystallisation or a dissolution-reprecipitation process where the unstable surface is dissolved in the solution and precipitated as a more stable surface takes place. These areas, indicated by arrows in Figure $4 \mathrm{f}$ appear to be similar to the single-crystalline islands observed on the surface of icositetrahedral shaped zeolite analcime [48], the first example found to follow the reversed crystal growth route. Instead of the predicted crystallisation route where a single nucleus or a few nuclei are followed by a layer-by-layer deposition of atoms, molecules or ions, re-crystallisation took place simultaneously on the whole surface. According to the mechanism of Ostwald ripening, small particles dissolve and redeposit onto larger particles in order to achieve a more thermodynamically stable state, we may speculate that the particles with smaller domains are at an early stage of crystal growth and the larger domains developed from the former.

A few nanocrystallites remaining in the centre of a (104) face as shown by the SEM micrograph in Figure $6 \mathrm{~d}$ indicates re-crystallisation started at the edges before extending to the centre of the faces. The driving force for fusing the crystalline islands and eventually the formation of a single crystalline polyhedral shell with six $\{104\}$ facets (Figure 7e), usually with an increase of reaction time, is said to be that to achieve a minimum surface free energy [70]. Reversed crystal growth examples have shown that surface re-crystallisation of the aggregates always leads to a polyhedral morphology with a minimised surface free energy even if the core region is disordered [48]. Therefore, the Curie-Wulff theorem $[71,72]$, stating that the equilibrium shape of a free crystal is that which minimizes its surface free energy can be applied to both single and polycrystalline crystals.

It is predicted that, over a longer period of time, crystallisation would extend from the surface to the core to increase the thickness of the rhombohedral shell (Figure 7f). The core-shell structure should eventually diminish to form a true single crystalline state. Ostwald ripening is said to be responsible for this step. This is thought to be the first time this reversed crystal growth route has been observed in nature, although Zhou and co-workers suspected that the formation of hollow agate stone (water agate) would follow a similar process [73].

Although the mid- and final-stage growth of the natural and synthetic calcite in the present work is very similar, our microstructural analysis implies that there may be some differences in the early growth steps. Growth of the synthetic calcite particles began with the formation of irregularly shaped aggregates of chitosan and $\mathrm{Ca}\left(\mathrm{NO}_{3}\right)\left(\mathrm{H}_{2} \mathrm{O}\right)_{3}$ precursor molecules/ions (Figure 7a') [18]. This was followed by the formation of calcite crystallites, which were often embedded in the composite particles (Figure $7 b^{\prime}$ ). Richie et al. [18] found the surface of the irregular composite particles was the most active site for the nucleation of calcite. This was said to be due to the trapping of the $\mathrm{Ca}^{2+}$ cations by the chitosan molecules and the slow release of $\mathrm{CO}_{3}{ }^{2-}$ anions from the decomposition of urea. The $-\mathrm{OH}$ 
and $-\mathrm{NH}_{2}$ functional groups of chitosan bound on the surface of the calcite crystallites suppressed their growth and prevented the growth of free crystals. Instead, they underwent aggregation to form polycrystalline particles with a rhombohedral appearance (Figure 7d).

Despite the short history of this reversed crystal growth route it has been used to explain the formation of many hollow and core-shell crystals in several inorganic systems including zeolites [48,74,75], perovskites [76], metal oxides [26,77], plus more recently organic resorcinarene hexamer [78], alloy nanoparticles [79] and metal organic frameworks [80,81]. There is a need for further extensive studies on the complex interactions between organic structure directing agents and metal cations to establish the role EPS plays in biomineralisation. Estroff and co-workers [23] carried out investigations on the nanoscale to understand the distribution of biomacromolecules in their synthetic calcite crystals prepared in the presence of agarose nanofibers. One important proposed question was why the three-dimensional networks of agarose nanofibers do not disrupt the rhombohedral morphology or the crystalline lattice of calcite. Due to difference in atomic number $(Z)$ between the organic polymer and calcite, annular dark-field scanning transmission electron microscopy (ADF-STEM) and electron tomography revealed, in three dimensions, that the agarose fibres formed a $3 \mathrm{D}$ random network that penetrated the entire calcite particle. Application of this methodology to the calcitic prisms from Atrina rigida shells effectively showed disk-like nanopatches consistent with organic inclusions preferentially aligned along the (00l) planes of calcite [82]. The nanopatches perpendicular to the $c$-axis of calcite inferred that the biomolecules preferentially absorb onto the homocharged $(00 l)$ faces. Preferential adsorption of organic molecules on the $(00 l)$ plane did not occur in the present travertine study. Instead EPS molecules adsorbed onto the (104) plane to result in building units displaying rhombohedral habits as summarised by our model in Figure 7. The authors of the present work realise that ADF-STEM and electron tomography [83] would be valuable techniques for this study but unfortunately have no access to such equipment.

\section{Materials and Methods}

\subsection{Collection of Travertine Specimen}

The travertine sample was collected from Erdaohai in Munigou Valley National Park, which is located in the northern part of the Sichuan Province, China. Erdaohai occurs in the northern part of Munigou and is a SW-NE orientated low gradient mountain valley with a length of approximately $3 \mathrm{~km}$. A few active warm springs, including a human-controlled pool and small mounds are present at the southwest end of Erdaohai (i.e., the upper part of the valley). The water temperature of the pool is about $20^{\circ} \mathrm{C}$ all year around, which is higher than the annual mean air temperature of $7^{\circ} \mathrm{C}$, and has a sulphur level of $0.16 \mathrm{mg} / \mathrm{L}$ (from tourist information). Thin travertine deposits with microbial mats occur at the bottom of the pool and also along the sides of the pool water exit channel. Northeastwards, Erdaohai valley comprises of a number of large and shallow-water pools with rims containing active travertine deposits. The travertine specimen was sampled from a seasonal-dried travertine pool rim and represents plant travertine deposits.

\subsection{Sample Characterization}

Powder X-ray diffraction (XRD) was performed on a PANalytical Empyrean diffractometer (Almelo, The Netherlands), using $\mathrm{Cu} \mathrm{K} \alpha$ radiation $(\lambda=1.5418 \AA)$. Analysis of the powder XRD patterns was carried out using Highscore plus software. SEM images of the specimens were obtained using a JEOL JSM-6700F (Akishima, Japan) field-emission gun microscope, operating at 1 to $5 \mathrm{kV}$. The travertine sample was prepared for SEM characterisation by lightly crushing with a pestle and mortar. Small travertine pieces with a dimension of several millimetres were placed on a sticky carbon tab mounted on a brass stub. To overcome beam charging problems, the specimen surface was coated with a thin gold film using a Quorum Technologies Q150R ES (Laughton, East Sussex, UK) sputter coater/carbon coater prior to SEM analysis. The FEG-SEM is equipped with an Oxford INCA 
system for energy dispersive X-ray spectroscopy (EDX), which was applied for examination of the local chemical compositions of the specimens. TEM images and SAED patterns were attained using a JEOL JEM-2011 (Akishima, Japan) electron microscope fitted with a $\mathrm{LaB}_{6}$ filament operating at an accelerating voltage of $200 \mathrm{kV}$. TEM images were recorded using a Gatan 794 CCD camera (Abingdon, UK). For TEM sample preparation, the natural and synthetic samples were lightly ground with a pestle and mortar and suspended in acetone. One drop of the suspension was deposited onto a $3 \mathrm{~mm}$ sized copper grid with a thin holey carbon support film coating. The solvent was allowed to evaporate then the grid was placed in the specimen holder. This electron microscope is also equipped with an Oxford Link ISIS SemiSTEM EDX system (High Wycombe, UK). Thermogravimetric analysis (TGA) was carried out on a Stanton Redcroft STA-780 (East Grinstead, West Sussex, UK) series instrument at a heating rate of $5^{\circ} \mathrm{C} / \mathrm{min}$ under air.

\section{Conclusions}

This study is a rare example to demonstrate that, despite the present travertine calcite system being a 'real' life example; it was possible to collect crystals with various ages and perform an electron microscopic study and thus propose a formation mechanism as well as make a comparison to synthetic calcite. The matrix macromolecules of EPS in this travertine crystallisation system, in a similar manner to the chitosan molecules added to the synthetic system disturbed the environment required for the crystal growth to follow the classical (with a single nucleation) route. This has previously been commonly observed when large organic agents were added to biomimetic systems. The inclusion of matrix molecules is thought to play several important roles, such as controlling the crystal size to a nanometer scale and inducing aggregation of nanocrystallites in the early stages $[38,65]$. The nucleation and growth of the calcite crystallites were suppressed by the attraction between the polar $-\mathrm{OH}$ and $-\mathrm{COOH}$ terminating groups of EPS and the $\mathrm{Ca}^{2+}$ cations located on the surface of the nanocrystallites. Core-shell calcite particles consisting of a polycrystalline core enclosed in a thin single crystal rhombohedral shell were generated by surface re-crystallisation of oriented aggregates. Further nanoscale characterisation using HRTEM imaging and electron diffraction is required to fully understand the structure before the driving force for such a perfect alignment of nanocrystallites in many naturally occurring biominerals can be comprehended. Finally, the step-by-step growth of calcite prepared in the presence of chitosan was demonstrated to be an effective simulation of the growth of the investigated travertine specimen. Obviously, the synthetic process taking place in a laboratory can be easily speeded up by controlling the conditions.

Supplementary Materials: The following are available online at http://www.mdpi.com/2073-4352/7/2/36/s1, Figure S1: SEM of calcite particles in the travertine specimen, Figure S2: Additional SEM images of calcite particles found in the travertine specimen, Figure S3: TGA of the travertine specimen, Figure S4: TEM images and corresponding SAED pattern of travertine calcite particles, Figure S5: TEM images of synthetic calcite prepared in the presence of chitosan, Figure S6: SEM images of synthetic calcite in absence of organic agents, Figure S7: SEM images of synthetic calcite prepared in the presence of gelatin.

Acknowledgments: Heather F. Greer would like to thank the University of St Andrews for the studentship, Ross Blackley for his help on using the SEM and TEM microscopes and Sylvia Williamson for performing TGA. Katherine Self plus a 3rd year undergraduate mini-project group, Angus W. Ritchie, Michael I. T. Watson, Robin Turnbull, Zhengzhong Lu, Michael Telfer, Jerome E. Gano for carrying out preliminary experiments. Wuzong Zhou thanks EPSRC for financial support on FEG-SEM equipment (EP/F019580/1) and a Platform (EP/K015540/1). Li Guo would like to thank TOTAL Pau for financial support for the fieldwork in China.

Author Contributions: Heather F. Greer and Wuzong Zhou conceived and designed the experiments; Heather F. Greer performed the experiments; Heather F. Greer and Wuzong Zhou analyzed the data; Li Guo contributed travertine specimen collection; Heather F. Greer wrote the paper.

Conflicts of Interest: The authors declare no conflict of interest.

\section{References}

1. Dickinson, S.R.; Henderson, G.E.; McGrath, K.M. Controlling the kinetic versus thermodynamic crystallisation of calcium carbonate. J. Cryst. Growth 2002, 244, 369-378. [CrossRef] 
2. Kawano, J.; Shimobayashi, N.; Miyake, A.; Kitamura, M. Precipitation diagram of calcium carbonate polymorphs: Its construction and significance. J. Phys. Condens. Matter 2009, 21, 425102. [CrossRef] [PubMed]

3. Pentecost, A. Travertine; Springer: Berlin, Germany, 2005.

4. Jones, B.; Renaut, R.W. Calcareous Spring Deposits in Continental Settings. In Developments in Sedimentology: Carbonates in Continental Settings: Facies, Environments and Processes; Elsevier: Amsterdam, The Netherlands, 2010; pp. 177-224.

5. Capezzuoli, E.; Gandin, A.; Pedley, M. Decoding tufa and travertine (fresh water carbonates) in the sedimentary record: The state of the art. Sedimentology 2014, 61, 1-21. [CrossRef]

6. Pedley, H.M. Classification and environmental models of cool freshwater tufas. Sediment. Geol. 1990, 68, 143-154. [CrossRef]

7. Kim, J.-W.; Kogure, T.; Yang, K.; Kim, S.-T.; Jang, Y.-N.; Baik, H.-S.; Geesey, G. The characterisation of CaCO 3 in a geothermal environment: A SEM/TEM-EELS study. Clays Clay Miner. 2012, 60, 484-495. [CrossRef]

8. Coman, C.; Chiriac, C.M.; Robeson, M.S.; Ionescu, C.; Dragos, N.; Barbu-Tudoran, L.; Andrei, A.-Ş.; Banciu, H.L.; Sicora, C.; Podar, M. Structure, mineralogy, and microbial diversity of geothermal spring microbialites associated with a deep oil drilling in Romania. Front. Microbiol. 2015, 6, 253. [CrossRef] [PubMed]

9. Best, J.L.; Fielding, C.R.; Jarvis, I.; Mozley, P. Sedimentology: Millenium Reviews-The Journal of the International Association of Sedimentologiests; Wiley-Blackwell: New York, NY, USA, 2009.

10. Decho, A.W. Microbial exopolymer secretions in ocean environments: Their role(s) in food webs and marine processes. Oceanogr. Mar. Biol. Annu. Rev. 1990, 28, 73-153.

11. Ruan, X.; Li, L.; Liu, J. Flocculating characteristic of activated sludge flocs: Interaction between $\mathrm{Al}^{3+}$ and extracellular polymeric substances. J. Environ. Sci. 2013, 25, 916-924. [CrossRef]

12. Pentecost, A. Association of cyanobacteria with tufa deposits: Identity, enumeration and nature of the sheath material revealed by histochemistry. Geomicrobiol. J. 1985, 4, 285-298. [CrossRef]

13. Plee, K.; Ariztegui, D.; Martini, R.; Davaud, E. Unravelling the microbial role in ooid formation-Results of an in situ experiment in modern freshwater Lake Geneva in Switzerland. Geobiology 2008, 6, 341-350. [CrossRef]

14. Pedley, M. The morphology and function of thrombolitic calcite precipitating biofilms: A universal model derived from freshwater mesocosm experiments. Sedimentology 2014, 61, 22-40. [CrossRef]

15. Riding, R. Microbial carbonates: The geological record of calcified bacterial-algal mats and biofilms. Sedimentology 2000, 47, 179-214. [CrossRef]

16. Okumura, T.; Takashima, C.; Shiraishi, F.; Akmaluddin; Kano, A. Textural transition in an aragonite travertine formed under various flow conditions at Pancuran Pitu, Central Java, Indonesia. Sediment. Geol. 2012, 265, 195-209. [CrossRef]

17. Jones, B.; Renaut, R.W. Noncrystallographic calcite dendrites from hot-spring deposits at Lake Bogoria, Kenya. J. Sediment. Res. 1995, 65, 154-169.

18. Ritchie, A.W.; Watson, M.I.T.; Turnbull, R.; Lu, Z.Z.; Telfer, M.; Gano, J.E.; Self, K.; Greer, H.F.; Zhou, W.Z. Reversed crystal growth of rhombohedral calcite in the presence of chitosan and gum arabic. CrystEngComm 2013, 15, 10266-10271. [CrossRef]

19. Xiao, J.; Zhu, Y.; Liu, Y.; Liu, H.; Zeng, Y.; Xu, F.; Wang, L. Vaterite selection by chitosan gel: An example of polymorph selection by morphology of biomacromolecules. Cryst. Growth Des. 2008, 8, 2887-2891. [CrossRef]

20. Chen, A.; Luo, Z.; Akbulut, M. Ionic liquid mediated auto-templating assembly of $\mathrm{CaCO}_{3}$-chitosan hybrid nanoboxes and nanoframes. Chem. Commun. 2011, 47, 2312-2314. [CrossRef] [PubMed]

21. Zhan, J.; Lin, H.-P.; Mou, C.-Y. Biomimetic formation of porous single-crystalline $\mathrm{CaCO}_{3}$ via nanocrystal aggregation. Adv. Mater. 2003, 15, 621-623. [CrossRef]

22. Nindiyasari, F.; Ziegler, A.; Griesshaber, E.; Fernàndez-Díaz, L.; Huber, J.; Walther, P.; Schmahl, W.W. Effect of hydrogel matrices on calcite crystal growth morphology, aggregate formation, and co-orientation in biomimetic experiments and biomineralization environments. Cryst. Growth Des. 2015, 15, 2667-2685. [CrossRef]

23. Li, H.; Xin, H.L.; Muller, D.A.; Estroff, L.A. Visualizing the 3D internal structure of calcite single crystals grown in agarose hydrogels. Science 2009, 326, 1244-1247. [CrossRef] [PubMed] 
24. Nindiyasari, F.; Fernàndez-Díaz, L.; Griesshaber, E.; Astilleros, J.M.; Sànchez-Pastor, N.; Schmahl, W.W. Influence of gelatin hydrogel porosity on the crystallization of $\mathrm{CaCO}_{3}$. Cryst. Growth Des. 2014, 14, 1531-1542. [CrossRef]

25. Tseng, Y.-H.; Lin, H.-Y.; Liu, M.-H.; Chen, Y.-F.; Mou, C.-Y. Biomimetic synthesis of nacrelike faceted mesocrystals of ZnO-gelatin composite. J. Phys. Chem. C 2009, 113, 18053-18061. [CrossRef]

26. Greer, H.F.; Zhou, W.Z.; Liu, M.-H.; Tseng, Y.-H.; Mou, C.-Y. The origin of ZnO twin crystals in bio-inspired synthesis. CrystEngComm 2012, 14, 1247-1255. [CrossRef]

27. Bauermann, L.P.; del Campo, A.; Bill, J.; Aldinger, F. Heterogeneous nucleation of ZnO using gelatin as the organic matrix. Chem. Mater. 2006, 18, 2016-2020. [CrossRef]

28. Liu, M.-H.; Tseng, Y.-H.; Greer, H.F.; Zhou, W.Z.; Mou, C.-Y. Dipole field guided orientated attachment of nanocrystals to twin-brush ZnO mesocrystals. Chem. Eur. J. 2012, 18, 16104-16113. [CrossRef] [PubMed]

29. Busch, S.; Dolhaine, H.; DuChesne, A.; Heinz, S.; Hochrein, O.; Laeri, F.; Podebrad, O.; Vietze, U.; Weiland, T.; Kniep, R. Biomimetic morphogenesis of fluorapatite-gelatin composites: Fractal growth, the question of intrinsic electric fields, core/shell assemblies, hollow spheres and reorganization of denatured collagen. Eur. J. Inorg. Chem. 1999, 1999, 1643-1653. [CrossRef]

30. Simon, P.; Rosseeva, E.; Buder, J.; Carrillo-Cabrere, W.; Kniep, R. Embryonic states of fluorapatite-gelatine nanocomposites and their intrinsic electric-field-driven morphogenesis: The missing link on the way from atomistic simulations to pattern formation on the mesoscale. Adv. Funct. Mater. 2009, 19, 3596-3603. [CrossRef]

31. Hernández-Hernández, A.; Rodríguez-Navarro, A.B.; Gómez-Morales, J.; Jiménez-Lopez, C.; Nys, Y.; García-Ruiz, J.M. Influence of model globular proteins with different isoelectric points on the precipitation of calcium carbonate. Cryst. Growth Des. 2008, 8, 1495-1502. [CrossRef]

32. Wang, T.; Cölfen, H.; Antonietti, M. Nonclassical crystallization: mesocrystals and morphology change of $\mathrm{CaCO}_{3}$ crystals in the presence of a polyelectrolyte additive. J. Am. Chem. Soc. 2005, 127, 3246-3247. [CrossRef] [PubMed]

33. Nan, Z.; Chen, X.; Yang, Q.; Wang, X.; Shi, Z.; Hou, W. Structure transition from aragonite to vaterite and calcite by the assistance of SDBS. J. Colloid Interface Sci. 2008, 325, 331-336. [CrossRef] [PubMed]

34. Seto, J.; Ma, Y.; Davis, S.A.; Meldrum, F.; Gourrier, A.; Kim, Y.-Y.; Schilde, U.; Sztucki, M.; Burghammer, M.; Maltsev, S.; Jäger, C.; Cölfen, H. Structure-property relationships of a biological mesocrystal in the adult sea urchin spine. Proc. Natl. Acad. Sci. USA 2012, 109, 3699-3704. [CrossRef] [PubMed]

35. Schmahl, W.W.; Griesshaber, E.; Kelm, K.; Goetz, A.; Jordan, G.; Ball, A.; Xu, D.; Merkel, C.; Brand, U. Hierarchical structure of marine shell biomaterials: Biomechanical functionalization of calcite by brachiopods. Z. Kristollogr. 2012, 227, 793-804. [CrossRef]

36. Qian, C.; Wang, R.; Cheng, L.; Wang, J. Theory of microbial carbonate precipitation and its application in restoration of cement-based materials defects. Chin. J. Chem. 2010, 28, 847-857. [CrossRef]

37. Lian, B.; Hu, Q.; Chen, J.; Ji, J.; Teng, H.H. Carbonate biomineralization induced by soil bacterium Bacillus megaterium. Geochim. Cosmochim. Acta 2006, 70, 5522-5535. [CrossRef]

38. Greer, H.F. Non-classical crystal growth of inorganic and organic materials. Mater. Sci. Technol. 2014, 30, 611-626. [CrossRef]

39. Niederberger, M.; Cölfen, H. Oriented attachment and mesocrystals: Non-classical crystallization mechanisms based on nanoparticle assembly. Phys. Chem. Chem. Phys. 2006, 8, 3271-3287. [CrossRef] [PubMed]

40. Volmer, M. Kinetik der Phasenbildung; Steinkopf: Leipzig, Germany, 1939.

41. Bravais, A. Études Cristallographiques; Gauthier-Villars: Paris, France, 1866.

42. Friedel, M.G. Études sur la loi de Bravais. Bull. Soc. Fr. Miner. Cristallogr. 1907, 30, 326-455.

43. Donnay, J.D.H.; Harker, D. A new law of crystal morphology extending the law of Bravais. Am. Miner. 1937, $22,446-467$.

44. Hartman, P.; Perdok, W.G. On the relations between structure and morphology of crystals. II. Acta Crystallogr. 1955, 8, 521-524. [CrossRef]

45. Ostwald, W. Lehrbuch der Allgemeinen Chemie; Wilhelm Engelmann: Leipzig, Germany, 1896; Volume 2, Part 1.

46. Boistelle, R.; Astier, J.P. Crystallization mechanisms in solution. J. Cryst. Growth 1988, 90, 14-30. [CrossRef]

47. Ueda, S.; Koizuma, M. Crystallization of analcime solid solutions from aqueous solutions. Am. Miner. 1979, $64,172-179$. 
48. Chen, X.Y.; Qiao, M.H.; Xie, S.H.; Fan, K.N.; Zhou, W.Z.; He, H.Y. Self-construction of core-shell and hollow zeolite analcime icositetrahedra: A reversed crystal growth process via oriented aggregation of nanocrystallites and recrystallization from surface to core. J. Am. Chem. Soc. 2007, 129, 13305-13312. [CrossRef] [PubMed]

49. Cartwright, J.H.E.; Checa, A.G. The dynamics of nacre self-assembly. J. R. Soc. Interface 2007, 4, 491-504. [CrossRef] [PubMed]

50. Weiner, S.; Lowenstam, H. Organization of extracellularly mineralized tissues: A comparative study of biological crystal growth. CRC Crit. Rev. Biochem. 1986, 20, 365-408. [CrossRef] [PubMed]

51. Gilis, M.; Grauby, O.; Willenz, P.; Dubois, P.; Heresanu, V.; Baronnet, A. Biomineralization in living hypercalcified demosponges: Toward a shared mechanism? J. Struct. Biol. 2013, 183, 441-453. [CrossRef] [PubMed]

52. Finnemore, A.; Cunha, P.; Shean, T.; Vignolini, S.; Guldin, S.; Oyen, M.; Steiner, U. Biomimetic layer-by-layer assembly of artificial nacre. Nat. Comm. 2012, 3, 966. [CrossRef] [PubMed]

53. Jones, B.; Renaut, R.W. Cyclic development of large, complex, calcite dendrite crystals in the Clinton travertine, interior British Columbia, Canada. Sediment. Geol. 2008, 203, 17-35. [CrossRef]

54. García-del-Cura, M.Á.; Benavente, D.; Martínez-Martínez, J.; Cueto, N. Sedimentary structures and physical properties of travertine and carbonate tufa building stone. Constr. Build. Mater. 2012, 28, 456-467. [CrossRef]

55. Wang, L.; Tang, R.; Bonstein, T.; Orme, C.A.; Bush, P.J.; Nancollas, G.H. A new model for nanoscale enamel dissolution. J. Phys. Chem. B 2005, 109, 999-1005. [CrossRef] [PubMed]

56. Li, H.; Estroff, L.A. Porous calcite single crystals grown from a hydrogel medium. CrystEngComm 2007, 9, 1153-1155. [CrossRef]

57. Asenath-Smith, E.; Li, H.; Keene, E.C.; She, Z.W.; Estroff, L.A. Crystal growth of calcium carbonate in hydrogels as a model of biomineralisation. Adv. Funct. Mater. 2012, 22, 2891-2914. [CrossRef]

58. Grassmann, O.; Müller, G.; Löbmann, P. Organic-Inorganic hybrid structure of calcite crystallline assemblies grown in a gelatin hydrogel matrix: Relevance to biomineralization. Chem. Mater. 2002, 14, 4530-4535. [CrossRef]

59. Sheng, G.-P.; Yu, H.-Q.; Li, X.-Y. Extracellular polymeric substances (EPS) of microbial aggregates in biological wastewater treatment systems: A review. Biotechnol. Adv. 2010, 28, 882-894. [CrossRef] [PubMed]

60. Liu, H.; Fang, H.H.P. Characterization of electrostatic binding sites of extracellular polymers by linear programming analysis of titration data. Biotechnol. Bioeng. 2002, 80, 806-811. [CrossRef] [PubMed]

61. Guibaud, G.; van Hullebusch, E.; Bordas, F. Lead and cadmium biosorption by extracellular polymeric substances (EPS) extracted from activated sludges: $\mathrm{pH}$-sorption edge tests and mathematical equilibrium modelling. Chemosphere 2006, 64, 1955-1962. [CrossRef] [PubMed]

62. Zhang, P.; Chen, Y.-P.; Guo, J.-S.; Shen, Y.; Yang, J.-X.; Fang, F.; Li, C.; Gao, X.; Wang, G.-X. Adsorption behavior of tightly bound extracellular polymeric substances on model organic surfaces under different $\mathrm{pH}$ and cations with surface plasmon resonance. Water Res. 2014, 57, 31-39. [CrossRef] [PubMed]

63. Sethmann, I.; Helbig, U.; Wörheide, G. Octocoral sclerite ultrastructures and experimental approach to underlying biomineralisation principles. CrystEngComm 2007, 9, 1262-1268. [CrossRef]

64. Jones, B.; Renaut, R.W. Skeletal crystals of calcite and trona form hot-spring deposits in Keyna and New Zealand. J. Sediment. Res. 1996, 66, 265-274.

65. Zhou, W.Z. Reversed crystal growth: Implications for crystal engineering. Adv. Mater. 2010, 22, 3086-3092. [CrossRef] [PubMed]

66. Song, R.-Q.; Cölfen, H. Mesocrystals-ordered nanoparticle superstructures. Adv. Mater. 2010, 22, $1301-1330$. [CrossRef] [PubMed]

67. Kim, Y.-Y.; Schenk, A.S.; Ihil, J.; Hetherington, N.B.J.; Tang, C.C.; Schmahl, W.W.; Griesshaber, E.; Hyett, G.; Meldrum, F.C. A critical analysis of calcium carbonate mesocrystals. Nat. Commun. 2014, 5, 4341. [CrossRef] [PubMed]

68. Yang, D.; Qi, L.; Ma, J. Well-defined star-shaped calcite crystals formed in agarose gels. Chem. Commun. 2003, 1180-1181. [CrossRef]

69. Dupraz, C.; Reid, R.P.; Braissant, O.; Decho, A.W.; Norman, R.S.; Visscher, P.T. Processes of carbonate precipitation in modern microbial mats. Earth-Sci. Rev. 2009, 96, 141-162. [CrossRef]

70. Greer, H.F.; Yu, F.J.; Zhou, W.Z. Early stages of non-classic crystal growth. Sci. China Chem. 2011, 54, 1867-1876. [CrossRef] 
71. Curie, P. Sur la formation des cristaux et sur les constants capillaires de leurdifférentes faces. Bull. Soc. Fr. Miner. Cristallogr. 1885, 8, 145-150.

72. Wulff, G. Velocity of growth and dissolution of crystal faces. Z. Kristallogr. 1901, 34, 449-530.

73. Yang, X.F.; Fu, J.X.; Jin, C.J.; Chen, J.A.; Liang, C.L.; Wu, M.M.; Zhou, W.Z. Formation mechanism of CaTiO 3 hollow crystals with different microstructures. J. Am. Chem. Soc. 2010, 132, 14279-14287. [CrossRef] [PubMed]

74. Greer, H.; Wheatley, P.S.; Ashbrook, S.E.; Morris, R.E.; Zhou, W.Z. Early stage reversed crystal growth of zeolite A and its phase transformation to sodalite. J. Am. Chem. Soc. 2009, 131, 17986-17992. [CrossRef] [PubMed]

75. Yao, J.F.; Li, D.; Zhang, X.Y.; Kong, C.H.; Yue, W.B.; Zhou, W.Z.; Wang, H.T. Cubes of zeolite A with an amorphous core. Angew. Chem. Int. Ed. 2008, 47, 8397-8399. [CrossRef] [PubMed]

76. Moreira, M.L.; Andrés, J.; Mastelaro, V.R.; Varela, J.A.; Longo, E. On the reversed crystal growth of BaZrO 3 decaoctahedron: Shape evolution and mechanism. CrystEngComm 2011, 13, 5818-5824. [CrossRef]

77. Karn, A.; Kumar, M.; Singh, V.N.; Mehta, B.R.; Aravindan, S.; Singh, J.P. Growth of indium oxide and zinc-doped indium oxide nanostructures. Chem. Vap. Depos. 2012, 18, 295-301. [CrossRef]

78. Sander, J.R.G.; Bučar, D.-K.; Baltrusaitis, J.; MacGillivray, L.R. Organic nanocrystals of the resorcinarene hexamer via sonochemistry: Evidence of reversed crystal growth involving hollow morphologies. J. Am. Chem. Soc. 2012, 134, 6900-6903. [CrossRef] [PubMed]

79. Yu, F.J.; Zhou, W.Z. Alloying and dealloying of CuPt bimetallic nanocrystals. Prog. Nat. Sci. Mater. 2013, 23, 331-337. [CrossRef]

80. Zheng, C.M.; Greer, H.F.; Chiang, C.-Y.; Zhou, W.Z. Microstructural study of the formation mechanism of metal-organic framework MOF-5. CrystEngComm 2014, 16, 1064-1070. [CrossRef]

81. Greer, H.F.; Liu, Y.H.; Greenaway, A.; Wright, P.A.; Zhou, W.Z. Synthesis and formation mechanism of textured MOF-5. Cryst. Growth Des. 2016, 16, 2104-2111. [CrossRef]

82. Li, H.; Xin, H.L.; Kunitake, M.E.; Keene, E.C.; Muller, D.A.; Estroff, L.A. Calcite prisms from mollusk shells (Atrina Rigida): Swiss-cheese-like organic-inorganic single-crystal composites. Adv. Funct. Mater. 2011, 21, 2028-2034. [CrossRef]

83. Thomas, J.M.; Midgley, P.A.; Ducati, C.; Leary, R.K. Nanoscale electron tomography and atomic scale high-resolution electron microscopy of nanoparticles and nanoclusters: A short survey. Prog. Nat. Sci. Mater. 2013, 23, 222-234. [CrossRef]

(c) 2017 by the authors; licensee MDPI, Basel, Switzerland. This article is an open access article distributed under the terms and conditions of the Creative Commons Attribution (CC BY) license (http:/ / creativecommons.org/licenses/by/4.0/). 